\title{
Residual Levels of Polychlorinated biphenyls (PCBs) in the Atlantic Mackerel (Scomber scombrus, Linnaeus, 1758) Marketed within a Niger Delta Community
}

\author{
Oiseoje M. Wangboje and Oghenefejiro Obotha-Adigo
}

\begin{abstract}
The residual levels of polychlorinated biphenyls (PCBs) in the Atlantic Mackerel, Scomber scrombrus (mean length $44.87 \mathrm{~cm}$, mean weight $478.35 \mathrm{~g}$ ) marketed in Asaba, Delta State, Nigeria, were determined by Gas Chromatographic (GC) technique in order to ascertain its suitability for human consumption. The summary statistics for the mean concentrations of detectable PCBs in S. scrombrus ranged from $0.04 \mathrm{mg} / \mathrm{kg}$ (PCB 153) to $0.65 \mathrm{mg} / \mathrm{kg}$ (PCB 126), with a total of $0.93 \mathrm{mg} / \mathrm{kg}$ while the mean concentrations of PCBs in S. scrombrus by market ranged from $0.02 \mathrm{mg} / \mathrm{kg}$ (PCB 153) at Cable market to $0.82 \mathrm{mg} / \mathrm{kg}$ (PCB 126) at Abraka market with no observed significant difference $(p>0.05)$ in the mean concentrations of $\mathrm{PCB} 153$ and $\mathrm{PCB} 169$ in fish between markets. The toxicity quotient (TQ) values for $\mathrm{PCBs}$ in $\mathrm{S}$. scrombrus ranged from 0.02 (PCB 153) to $0.33(P C B$ 126) while the estimated daily intake (EDI) values in $\mathrm{mg} /$ person/day for PCBs ranged from 0.00072 (PCB 138) to 0.026 (PCB 126). A toxic equivalency (TEQ) value of 0.0656 was recorded with PCB 126 having the highest Sub-TEQ value of 0.065 while the total PCB content in S. scrombrus according to market ranged from $0.67 \mathrm{mg} / \mathrm{kg}$ (Cable market) to $1.20 \mathrm{mg} / \mathrm{kg}$ (Abraka market). The observed PCB levels in fish fell below International threshold values indicating suitability for human consumption. However constant monitoring of this aquatic species for hazardous levels of PCBs was highly recommended.
\end{abstract}

Index Terms - Polychlorinated biphenyls, Scomber scrombrus, Toxic equivalency.

\section{INTRODUCTION}

Polychlorinated biphenyls (PCBs) are synthetic and persistent organic pollutants (POPs) that were once massively produced for a host of electrical and industrial applications [1]. They are one of the 12 groups of POPs initially listed in the Stockholm Convention on POPs [2]. These substances which go by the trade name Aroclor, are essentially mixtures of 209 individual chlorinated compounds or congeners which still abound in the aquatic environment despite the outright stoppage of their manufacture decades ago. For example, they have been banned in the United States of America since 1979 [3]. Their persistence in the environment has been linked to their low degree of degradability, widespread use, redistribution, high thermal resistance and ability to readily bioaccumulate in the soft and fatty tissues of wildlife including fish [4]-[6]. PCBs principally migrate into the environment as a result of accidental spills and leaks from products containing Aroclor mixtures and then become redistributed amongst environmental compartments by volatilization and runoff

Published on August 25, 2020.

O. M. Wangboje, University of Benin, Nigeria.

(e-mail: oiseoje.wangboje ${ }^{\circledR}$ uniben.edu)

O. Obotha-Adigo, University of Benin, Nigeria.

(e-mail: fejiroobotha@gmail.com)
[7]. The aquatic environment has been observed to be the final end point for both persistent organic and inorganic pollutants which has led to the establishment of fish advisories in order to protect the health of man who may consume heavily contaminated fish [8]. According to the United States Environmental Protection Agency [9] fifty (50) states and some U.S. territories currently issue advisories to protect people from potential health risks of consuming tainted fish harvested from local waters. PCBs are vital in ecotoxicological researches around the world owing to their carcinogenic, mutagenic and teratogenic potentials [10]. To this end, the United States Environmental Protection Agency (USEPA) has clearly categorized PCBs as probable human carcinogens belonging to Group B2 [11]. PCBs are known to disrupt the growth, reproduction, endocrine systems and enzyme activities of aquatic species including fish. They can also cause mortality amongst Piscean communities [12] and become a serious threat to aquatic ecosytems and human health once bound to sediment particles [13]. Measureable and hazardous concentrations of PCBs have been detected in fish from North America, Europe, the United Kingdom, Atlantic and Pacific Oceans and Gulf of Mexico [14], [15]. Owing to the toxic and deleterious nature of PCBs, several Governments around the world have developed monitoring programmes in order to keep levels below hazardous limits. For example, in Japan, sophisticated analytical measures have been adopted and applied since 2002 to monitor the levels of PCBs in fish, air, water and sediment [16]. In Nigeria, reports regarding the presence of $\mathrm{PCBs}$ in natural aquatic media and fish are relatively few [17]. It therefore becomes pertinent to carry out more research on the PCB content in commonly consumed imported fish species in the country against the backdrop that Nigeria has been reported to be the largest fish consuming Nation on the African continent with an annual consumption of about 3.2 million metric tons of which 2.1 million tons are imported annually [18]. The Niger Delta region of Nigeria plays host to a diverse composition of natural aquatic media including Rivers, Creeks, Streams, Tributaries, Swamps and Ponds. The region is particularly known for fishing and crude oil exploration activities. Asaba, the administrative capital of Delta State, Nigeria, was the focal point of this research, as there is paucity of ecotoxicological data on the PCB content in fish marketed in this Niger Delta town. In this light, the potential health risk to humans consuming seafood contaminated with hazardous chemical substances has been emphasized [19]. The fish species of interest (FSI) was the Atlantic Mackerel (Scomber scrombrus, Linnaeus, 1758), commonly called "Scubia" in the local parlance. This fish 
species is widely consumed in Asaba and has been reported to be imported into the country from European countries, such as Norway [20]. According to the Food and Agriculture Organization of United Nations (FAO), the fish has been described as an epipelagic and mesodemersal species that is most abundant in cold and temperate waters of the world [21]. The fundamental working hypothesis of this research is that it may be possible to find residual levels of PCBs in S. scombrus that are being marketed within the study area. Data generated from the research have been compared to international thresholds for PCB in fish with a view to guiding both actual and potential consumers of the aforementioned experimental fish species.

\section{MATERIALS AND METHODS}

\section{A. The study area}

Asaba (Fig. 1) is a fast developing urban area with a metropolitan population of over half a million people. Geographically, it is gridlocked between Longitude $6^{\circ} 11^{\prime} \mathrm{N}$ and Latitude $6^{\circ} 44^{\prime} \mathrm{E}$ in Delta State, Nigeria, West Africa and has an average tropical temperature of $32^{\circ} \mathrm{C}$ during the dry season and an average rainfall of 2,700 millimeters during the rainy season. The town forms a strategic link between the western, eastern and northern regions of Nigeria through the popular River Niger [22]. After a presurvey of markets, four (4) markets namely Ogbogonogo, Cable, Midwifery and Abraka were eventually purposely selected for the collection of fish samples owing to the relative abundance of $S$. scrombrus in these markets.

\section{B. Procurement of samples of fish}

Fishes were purchased from the aforementioned markets between June and November 2019. They were placed in new polythene bags, sealed with selotape, labeled and moved to the laboratory in a Thermolineo $\AA$ ice chest within 24 hours.

\section{Laboratory studies and protocol}

The identity of fish species $(n=48)$ was confirmed using the electronic version of the Food and Agriculture Organization of the United Nations (FAO) species identification/fact sheet [21]. Total length (cm) measurements were taken using a measuring board while weight ( $\mathrm{g}$ ) of fish samples were measured using an electronic scale (Mettler ${ }^{\circledR}$ PM4800 Delta Range). The mean total length was $44.87 \mathrm{~cm}$ while the mean weight was $478.35 \mathrm{~g}$ (Table 1). All reagents and chemicals used were of analytical grade (BDH, Poole, England and Sigma, USA). All glassware was soaked in detergent and then rinsed alternately with running tap water and distilled water. Ten (10) $\mathrm{g}$ of muscle tissue was excised from the flanks with a stainless steel lancet and ground with anhydrous sodium sulphate until a completely dry homogenate was obtained. The extraction of PCB in fish tissue was performed according to standard procedures [23].

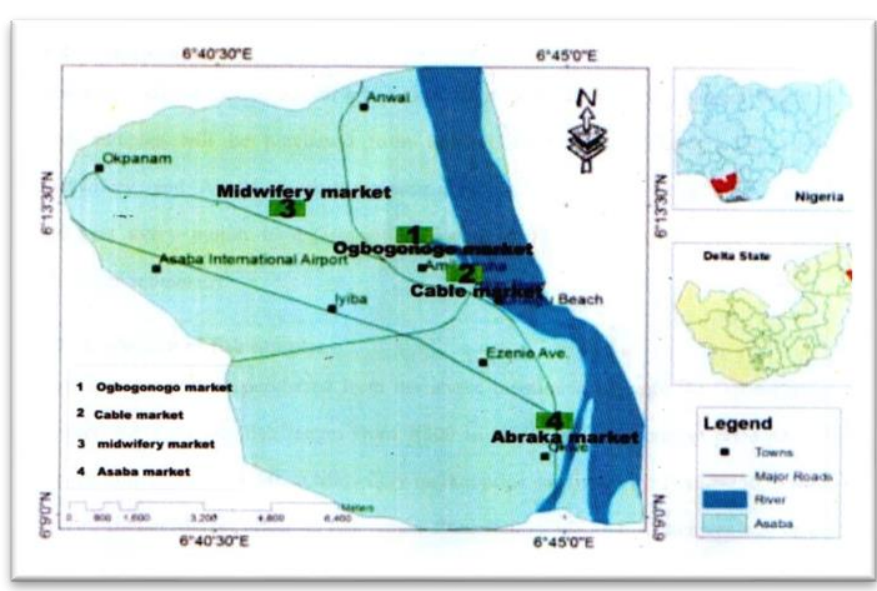

Fig. 1. Map of the study area.

The extract was concentrated to $2 \mathrm{ml}$ with a rotary evaporator (rotovap) at $40{ }^{\circ} \mathrm{C}$. The concentrated extract was thereafter used for clean-up and for gravimetric lipid determination. Clean-up of extracts was done in line with the method by [24] while a Perkin ${ }^{\circledR}$ model 5890 gas chromatograph equipped with $\mathrm{Ni} 63$ electron capture detector was used for quantification of PCBs. The quality control was performed by regular analyses of procedural blanks and blind duplicate samples along with random injection of standards and solvent blanks.

TABLE I: MORPHOMETRIC MEASUREMENTS FOR EXPERIMENTAL SCOMBER

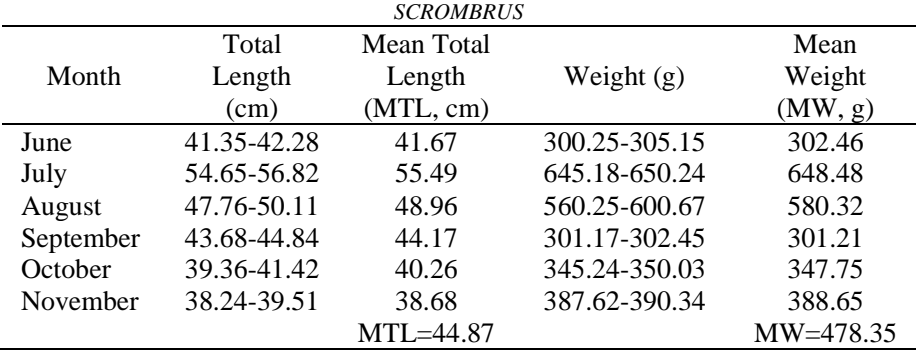

\section{Estimation of Daily Intake (EDI) of PCBs by man}

The EDI was calculated based on the method by [25], [26].

$$
\begin{gathered}
\mathrm{EDI}=40 \mathrm{~g} / \text { person } / \text { day } *(\mathrm{CPCB}) \mathrm{mg} / \mathrm{kg} / 1000 \mathrm{~g} / \mathrm{kg}= \\
=\mathrm{X} \mathrm{mg} / \text { person } / \text { day }
\end{gathered}
$$

Where:

40g/person/day = Estimated average fish consumption in the Niger Delta belt, Nigeria.

$(\mathrm{CPCB})=\mathrm{PCB}$ concentration in fish

\section{E. Toxicity/hazard quotient (TQ) for PCBs}

The Toxicity/hazard quotient (TQ) for chemical elements is a comparison of the measured concentration of siterelated chemical elements in ecological matrices with specific health-based criteria [27], [28].

$$
\mathrm{TQ}=\frac{\text { Concentration of PCB in fish sample }}{\text { Health based criteria }}
$$

\section{F. Toxic equivalency (TEQ) for PCBs}

According to [29, 30], the toxic equivalency (TEQ) for PCBs is expressed as follows: 


$$
\mathrm{TEQ}=\sum \mathrm{PCBi} * \mathrm{TEF}
$$

Where TEQ = Toxic equivalency,

$\mathrm{PCBi}=\mathrm{PCB}$ concentration in fish,

$\mathrm{TEF}=$ Toxic equivalency factor for specific congener.

\section{G. Statistical methods}

GENSTAT ${ }^{\circledR}$ computer software (Version 12.1 for Windows) was used for statistical analysis. Data were subjected to Analysis of variance (ANOVA) to determine significant differences between mean values of PCBs while significance means $(\mathrm{P}<0.05)$ were separated with Duncan multiple range test (DMRT). Microsoft ${ }^{\circledR}$ Excel (for windows 2010) was used for all graphical presentations.

\section{RESULTS}

The summary statistics for the mean concentrations of detectable PCBs in Scomber scrombrus ranged from 0.04 $\mathrm{mg} / \mathrm{kg}$ for PCB 153 to $0.65 \mathrm{mg} / \mathrm{kg}$ for PCB 126 as shown in Table II while the mean concentrations of detectable PCBs in $S$. scrombrus by market ranged from $0.02 \mathrm{mg} / \mathrm{kg}$ (PCB 153) at Cable market to $0.82 \mathrm{mg} / \mathrm{kg}$ (PCB 126) at Abraka market with no observed significant difference $(p>0.05)$ in the mean concentrations of PCB 153 and PCB 169 in fish between markets (Table III). The mean concentrations of detectable PCBs in $S$. scrombrus by month ranged from $0.02 \mathrm{mg} / \mathrm{kg}$ (PCB 153) in August to $0.68 \mathrm{mg} / \mathrm{kg}$ (PCB 126) in July with no observed significant difference $(p>0.05)$ in the mean concentrations of the PCB congeners in fish between months (Table IV). The toxicity quotient (TQ) values for PCBs in S. scrombrus ranged from 0.02 for PCB 153 to 0.33 for PCB 126 as presented in Fig. 2 while the estimated daily intake (EDI) values in $\mathrm{mg} /$ person/day for PCBs ranged from 0.00072 (PCB 138) to 0.026 (PCB 126) as shown in Fig. 3. As presented in Fig. 4, a TEQ value of 0.0656 was recorded with PCB 126 having the highest SubTEQ value of 0.065 while the total PCB content in $S$. scrombrus according to market ranged from $0.67 \mathrm{mg} / \mathrm{kg}$ at Cable market to $1.20 \mathrm{mg} / \mathrm{kg}$ at Abraka market (Fig. 5). The overall quota for PCB congeners in S. scrombrus ranged from $4.30 \%$ for PCB 153 to $69.89 \%$ for PCB 126 as shown in Figure 6 while the specific PCB quota in S. scrombrus according to market ranged from $2.98 \%$ (PCB 153) at Cable market to $76.11 \%$ (PCB 126) also at Cable market (Fig. 7).

TABLE II: SUMMARY STATISTICS FOR CONCENTRATIONS OF DETECTABLE PCBS (MG/KG) IN SCOMBER SCROMBRUS

\begin{tabular}{ccccc}
\hline Congener & Mean & Minimum & Maximum & Threshold \\
\hline PCB 126 & 0.65 & 0.42 & 0.88 & 2.0 \\
PCB 138 & 0.18 & 0.09 & 0.33 & 2.0 \\
PCB 153 & 0.04 & 0.00 & 0.08 & 2.0 \\
PCB 169 & 0.06 & 0.02 & 0.09 & 2.0 \\
\hline
\end{tabular}

TABLE III: MEAN CONCENTRATIONS OF DETECTABLE PCBS (MG/KG) IN SCOMBER SCROMBRUS BY MARKET

\begin{tabular}{ccccc}
\hline Market & PCB 126 & PCB 138 & PCB 153 & PCB 169 \\
\hline Ogbogonogo & $0.77^{\mathrm{a}}$ & $0.22^{\mathrm{b}}$ & $0.04^{\mathrm{a}}$ & $0.06^{\mathrm{a}}$ \\
Cable & $0.51^{\mathrm{b}}$ & $0.09^{\mathrm{b}}$ & $0.02^{\mathrm{a}}$ & $0.05^{\mathrm{a}}$ \\
Midwifery & $0.48^{\mathrm{b}}$ & $0.18^{\mathrm{a}}$ & $0.05^{\mathrm{a}}$ & $0.06^{\mathrm{a}}$ \\
Abraka & $0.82^{\mathrm{a}}$ & $0.24^{\mathrm{a}}$ & $0.06^{\mathrm{a}}$ & $0.08^{\mathrm{a}}$ \\
\hline
\end{tabular}

Means with the same superscripts are not significantly different ( $p>0.05$ ). Vertical comparisons only.
TABLE IV: MEAN CONCENTRATIONS OF DETECTABLE PCBS (MG/KG) IN SCOMBER SCROMBRUS BY MONTH

\begin{tabular}{ccccc}
\hline Month & PCB 126 & PCB 138 & PCB 153 & PCB 169 \\
\hline June & $0.62^{\mathrm{a}}$ & $0.12^{\mathrm{a}}$ & $0.04^{\mathrm{a}}$ & $0.04^{\mathrm{a}}$ \\
July & $0.68^{\mathrm{a}}$ & $0.17^{\mathrm{a}}$ & $0.03^{\mathrm{a}}$ & $0.06^{\mathrm{a}}$ \\
August & $0.67^{\mathrm{a}}$ & $0.17^{\mathrm{a}}$ & $0.02^{\mathrm{a}}$ & $0.07^{\mathrm{a}}$ \\
September & $0.66^{\mathrm{a}}$ & $0.17^{\mathrm{a}}$ & $0.05^{\mathrm{a}}$ & $0.07^{\mathrm{a}}$ \\
October & $0.61^{\mathrm{a}}$ & $0.23^{\mathrm{a}}$ & $0.05^{\mathrm{a}}$ & $0.07^{\mathrm{a}}$ \\
November & $0.65^{\mathrm{a}}$ & $0.23^{\mathrm{a}}$ & $0.06^{\mathrm{a}}$ & $0.07^{\mathrm{a}}$ \\
\hline
\end{tabular}

Means with the same superscripts are not significantly different ( $p>0.05)$. Vertical comparisons only.

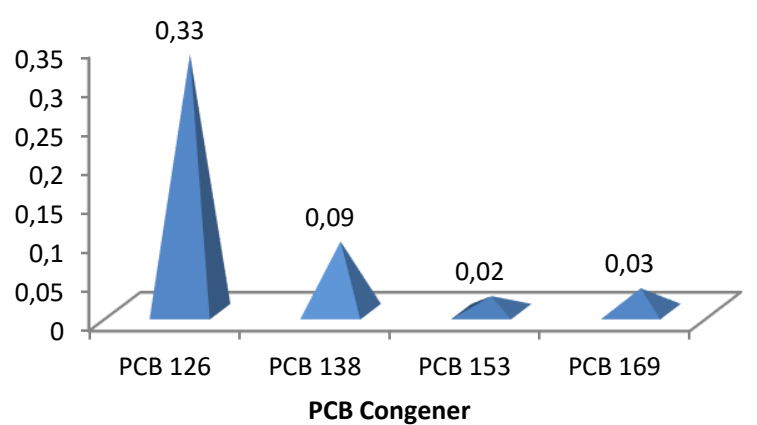

Fig. 2: Toxicity quotient (TQ) values for PCBs in Scomber scrombrus.

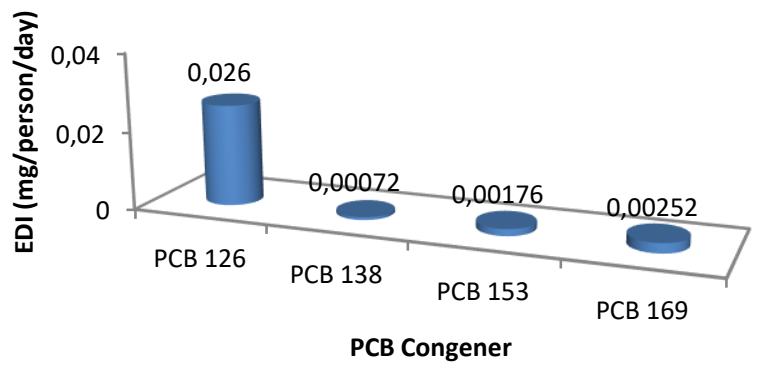

Fig.3: Estimated daily intake (EDI) values for PCBs.

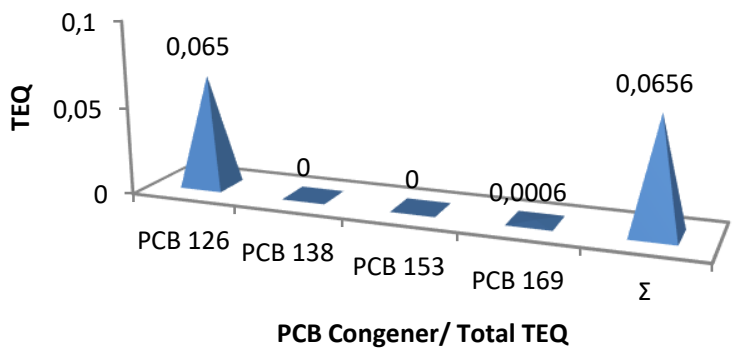

Fig 4: Toxic equivalency (TEQ) for PCBs in Scomber scrombrus.

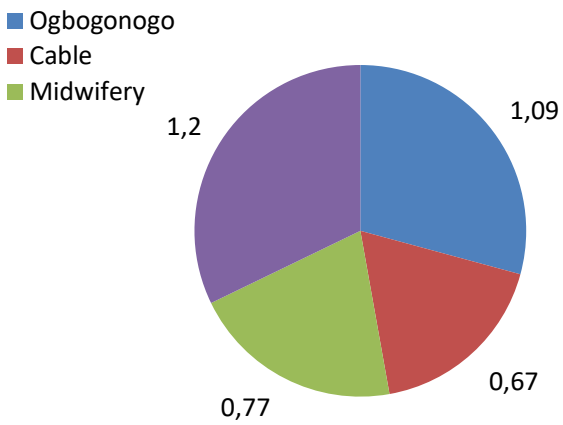

Fig. 5. Total PCB content $(\mathrm{mg} / \mathrm{kg})$ in Scomber scrombrus according to market. 


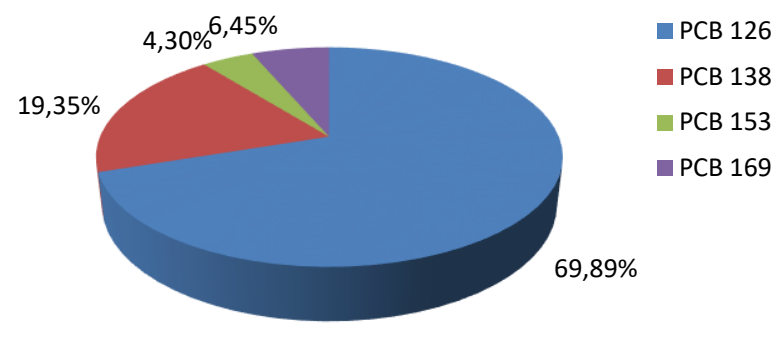

Fig. 6. The overall quota for PCB congeners in Scomber scrombrus.

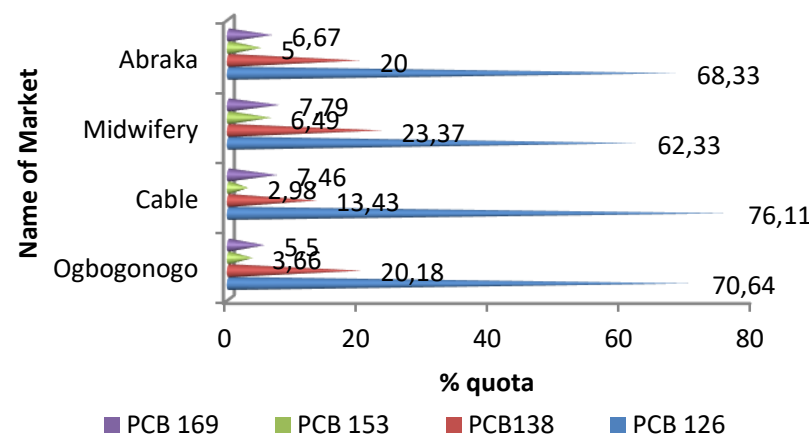

Fig. 7. Specific PCB quota in Scomber scrombrus according to market.

\section{DISCUSSION}

Four (4) out of the recognized and existing 209 PCB congeners were detected in S. scrombrus in this research. They were PCBs 126, 138, 153 and 169. The IUPAC names for these congeners are

3,3',4,4',5-Pentachlorobiphenyl,

Hexachlorobiphenyl, 2,2',4,4',5,5'-Hexachlorobiphenyl and 3,3',4,4',5,5'-Hexachlorobiphenyl respectively. PCBs 126 and 169 are also known as non-ortho PCBs or coplanar PCBs (cPCBs) and are regarded as "dioxin-like" congeners while PCB 138 and PCB 153 are "non-dioxin like" congeners [31-32]. The mean concentrations of PCB congeners in $S$. scrombrus took the rank profile PCB $126>\mathrm{PCB} 138>\mathrm{PCB} 169>\mathrm{PCB} 153$, with $\mathrm{PCB} 126$ accounting for well over half $(69.89 \%)$ of the amount of detectable PCBs. A similar trend was observed with the quota of PCB 126 in fish according to individual markets. These congeners were probably detected in S. scrombrus as a result of bioaccumulation in which case these substances were not metabolized quickly enough by the fish species which resulted in this scenario. It has been observed that wildlife including fish can easily bioaccumulate xenobiotics such as PCBs especially when such substances are available in much higher levels in the environment than what is obtainable within the host organism [33]. Dietary bioaccumulation of POPs in the common sole Solea solea from French waters has been reported [34]. From a biochemical point of view, PCBs would be expected to bioaccumulate to varied levels in fish owing to their unique composition and location of chlorine atoms which would invariably exhibit different potential for bioavailability and consequent uptake by fish. This opinion lends credence to the observation by [35] who noted that different PCB congeners show different distribution patterns in environmental media. The species of fish, feeding habitat/trophic position and specific conditions of the habitat, may influence the distribution of PCBs in the body of such fish [36]. Furthermore, PCBs are lipophilic substances which can easily build up in the fatty tissues of recipient organisms. An investigation on the PCB levels in the Lagos Lagoon, Nigeria revealed PCB values $(\mathrm{mg} / \mathrm{kg})$ of 0.00 and 0.02 for PCB 138 and PCB 153 in Tilapia zillii. PCB 126 and PCB169 were not detected in that study but the authors attributed the PCB content in the Lagoon to anthropogenic impact [17]. Much higher concentrations of total PCBs in the Rock Sole (Lepidopsetta bilineata) and Rock Greenling (Hexagrammos lagocephalus) of 285 $\mathrm{mg} / \mathrm{kg}$ and $104 \mathrm{mg} / \mathrm{kg}$ respectively from the Aleutia Islands of Alaska was reported by [37] clearly suggesting a much higher level of anthropogenic impact. As observed by the Alabama Fish Consumption Advisories [38] PCBs abound in the fatty areas of fish and by removing such fatty pieces the amount of contaminants eaten by man can be reduced drastically. Regarding the levels of PCBs in fish by market, there was no observed significant difference $(p>0.05)$ in the mean concentrations of PCB 153 and PCB 169 in fish between markets, suggesting that such fish may have been sourced from the same distributor. It was further observed that Cable and Abraka markets had the lowest and highest total PCB levels compared to the other markets suggesting that prospective buyers of $S$. scrombrus could visit the former for the purchase of this fish species owing to the obvious lower PCB burden. Regarding the levels of PCBs in fish by month, there was no observed significant difference $(p>0.05)$ in the mean concentrations of PCBs in fish between months, suggesting a relatively steady profile of PCBs in the sampled fish species during the period of research. The TQ values for non-carcinogenic risk revealed that none of such values exceeded unity even though PCB 126 had the highest value of 0.33 . This observation is a clear indication that all the detected PCBs do not presently portray a risk to potential consumers of the product. The EDI values for PCBs were lowest and highest for PCB $138(0.00072 \mathrm{mg} /$ person/day $)$ and PCB $126 \quad(0.026$ $\mathrm{mg} / \mathrm{person} /$ day) respectively. This trend is clearly linked with the lowest and highest mean concentrations of PCBs in fish. According to [39] the direction in which the EDI follows is directly related to the concentrations of contaminants in fish, thus the highest EDI value will be obtained for the contaminant with the highest concentration in fish and vice-versa. The overall TEQ value in this research was 0.0656 with PCB 126 accounting for a hefty $99 \%$ of this figure, suggesting a greater potency over the other detected PCBs. In order to be able to sum up the toxicity of different PCB congeners, toxic equivalency factors (TEFs) are applied to facilitate risk assessment and regulatory control [30]. In addition, in order to compare the toxicity of different samples, TEFs are generally used [40]. TEFs have so far been established for several congeners including PCB 126 and PCB 169. However, these factors are not available for PCBs 138 and 153 hence their exclusion from the overall TEQ computation. Regarding the direct human health risk via the consumption of $S$. scrombrus marketed in Asaba, both the total PCB level $(0.93 \mathrm{mg} / \mathrm{kg})$ and individual mean concentrations of the respective congeners did not exceed the $2.0 \mathrm{mg} / \mathrm{kg}$ threshold as established by [4]-[42]. This observation indicates that the consumption of $S$. scrombrus is relatively safe for 
human consumption, an assertion that has been buttressed by the TQ values earlier mentioned.

\section{CONCLUSION}

The levels of detectable PCB congeners in S. scrombrus marketed in Asaba, Delta State, Nigeria, has been successfully presented. It is commendable to observe that the concentrations of these persistent organic pollutants in the experimental fish species fell below established International thresholds thus indicating the suitability of such fish for human consumption. However, the ideal situation is not to have any trace or residue of PCBs in fish as their presence in fish is actually not a welcome development against the myriad of potential health problems that they are known to cause. In this light, constant monitoring of this aquatic species for hazardous levels of PCBs is highly recommended as a non-hazardous outcome today may not be the case in future. This research is thus considered to be an integral part of such monitoring efforts.

\section{ACKNOWLEDGMENT}

The authors are grateful to the Faculty of Agriculture, University of Benin, Benin City, Nigeria for providing general laboratory space and to SplendidStan Environmental Laboratory, Benin City, for the use of their Gas Chromatographic facility.

\section{REFERENCES}

[1] S.L.White, D.A. DeMario, D.A., L.R Iwanowicz, V.S. Blazer, and T. Wagner, "Tissue distribution and immunomodulation in Channel Catfish (Ictalurus punctatus) following dietary exposure to Polychlorinated biphenyl aroclors and food deprivation", International Journal of Environmental Research and Public Health, vol. 17, pp. 1228, 2020. doi:10.3390/ijerph17041228.

[2] E. Nyberg, S. Danielsson, U. Eriksson, S. Faxneld, A. Miller, and A. Bignert, "Spatio-temporal trends of PCBs in the Swedish freshwater environment 1981-2012”. Ambio, vol. 43, no.1, pp. 45-57, 2014. doi: 10.1007/s13280-014-0561-4.

[3] T. Butterworth, "PCBs in Salmon. Anatomy of a health scare." The Statistical Assessment Service (STATS), Center for Media and Public Affairs, Washington DC, 2004, 16 pp.

[4] A. Barakat, M. Khairy, and I. Aukaily, "Bioaccumulation of organochlorine contaminants in fish species from Lake Qarun, a protected area of Egypt". Toxicology and Environmental Chemistry, vol. 99, no. 1, pp. 117-133, 2017.

[5] M. Abalos, D. Barcelo, J. Parera, M. LaFarre, M. Llorca, E. Eljarrat, M.Giulivo, E. Capri, M. Paunovic, R. Milacic, and E. Abad, "Levels of regulated POPs in fish samples from the Sava River Basin. Comparison to legislated quality standard values". Science of the Total Environment, vol. 2019, pp.20-28, 2018.doi.org/10.1016/j.scitotenv.2018.07.371.

[6] A. Dendievel, B. Mourer, A.Coynel, O. Evrard, P. Labadie, S. Ayrault, M. Debret, F. Koltalo, Y. Copard, Q. Faivre, T. Gardes, S. Vauclin, H. Budzinski, C.Grosbois, T. Winiarski, and M. Desmet, "Spatio-temporal assessment of the Polychlorinated biphenyl (PCB) contamination in four major French River corridors (1945-2018)". Earth Systems and Scientific Data, vol. 12, pp. 1153-1170, 2020. doi.org/10.5194/essd-12-1153-2020.

[7] S. Klasing and R. Brodberg, "Development of fish contamination goals and advisory tissue levels for common contaminants in California sport fish: Chlordane, DDTs, Dieldrin, Methylmercury, PCBs, Selenium and Toxaphene." Pesticide and Environmental Toxicology Branch Office of Environmental Health Hazard Assessment, California Environmental Protection Agency, U.S.A. 2008, 115 pp.
[8] J. Ali and D. Larson, "Human health risk assessment of fish consumption and detected PFAS at Squam Lake." Department of Environmental Services, State of New Hampshire, United States of America. 2020, 6pp.

[9] United States Environmental Protection Agency, "Fish and shellfish advisories and safe eating guidelines 2020."Available: www.epa.gov/choose-fish-and-shellfish-wisely/fish-and-shellfishadvisories-and-safe-eating-guidelines Accessed 9th August, 2020.

[10] D. Lakhmanov, Y. Varakina, A. Aksenov, T. Sorokina, N. Sobolev, D. Kotsur, E. Plakhina, V. Chashchin, and Y.Thomassen, "Persistent organic pollutants (POPs) in fish consumed by the indigenous peoples from Nenets Autonomous Okrug." Environments, vol.7,2020. doi.10.3390/environments7010003.

[11] United States Environmental Protection Agency, (1999). "Polychlorinated biphenyls (PCBs) update: Impact on fish advisories". USEPA Office of Water, 4305. EPA-823-F-99-019, 1999, 7pp.

[12] O.A. Davis and P.A. Anwuri, "Polychlorinated biphenyl contamination in aquatic organisms in Nigerian inland waters." International Journal of Research Studies in Science, Engineering and Technology, vol. 7, no. 1, 2020, pp. 1-8.

[13] M. Urbaniak, S. Lee, and M. Takazawa, "Effects of soil amendment with PCB-contaminated sediment on the growth of two cucurbit species." Environmental Science Pollution Research, vol. 27, pp.8872-8884,2020. doi.org/10.1007/s11356-019-06509-9.

[14] R. Eisler and A.A. Belisle, "Planar PCB hazards to fish, wildlife and invertebrates: A synoptic review." Contaminant Hazard Reviews, Biological Report Number 31. Patuxent Wildlife Research Center, U.S. National Biological Service, Laurel, MD 20708, 1996, 96 pp.

[15] B. E. Carr, "Polychlorinated biphenyls, organochlorine pesticides and polycyclic aromatic hydrocarbons in Snapper (Family Lutjanidae) from Cuba and the Wider Gulf of Mexico." Graduate Theses and Dessertatons, University of South Florida, 2020, 62 pp.Available:https://scholarcommons.usf.edu/etd/8173 Accessed 14th August, 2020.

[16] The National Implementation Plan of Japan, "Stockholm convention on persistentorganic pollutants." $2016,121 \mathrm{pp}$.

[17] D. Adeyemi, G. Ukpo, C. Anyakora, and J.P. Uyimadu, "Polychlorinated biphenyl in fish samples from Lagos Lagoon, Nigeria." African Journal of Biotechnology, vol. 8, no. 12, pp. 28112815, 2009.

[18] World Fish Center, Available:https:www.worldfishcenter.org/country-pages/Nigeria. Accessed $3^{\text {rd }}$ August, 2020.

[19] S. Selvam, S. Venkatramanan, M.B. Hossain, S.Y. Chung, R. Khatibi, and A.A. Nadiri,"A study of health risk from accumulation of metals in commercial edible fish species at Tuticorin Coasts of Southern India." Estuarine Coastal and Shelf Science, doi.org/10.1016/j.ecss.2020.106929.

[20] O. M. Wangboje, S. Akaehomen, and M. Erhayimwen, "Human health risk assessment in relation to heavy metals in the Atlantic mackerel (Scomber scrombrus, L., 1758) sold in some major markets in Benin City, Nigeria." Tropical Journal of Natural Product Research, vol. 1, no. 1, pp. 32-38, 2017. doi.org/10.26538/tinpr/vli1.6.

[21] Foods and Agriculture Organization of the United Nations, "Species fact sheets. Scomber scombrus (Linnaeus, 1758)."Available:www.fao.org/fishery/species/2473/en Accessed June $7^{\text {th }}, 2019$.

[22] Wikipedia,Available:http://en.m.wikipedia.org/wiki/Asaba,_Delta. Accessed August $3^{\text {rd }}, 2020$.

[23] United States Environmental Protection Agency,"Method 8082: PCBs by Gas Chromatography." USEPA, Washington, DC, USA, 1996.

[24] E. Kampire, G. Rubidge, and J.B. Adams, "Distribution of polychlorinated biphenyl residues in several tissues of fish from the North End Lake, Port Elizabeth, South Africa." Water SA, vol.41, no. 4, pp. 559-570, 2015. doi.org/10.4314/wsa.v41i4.16.

[25] C. Anyakora, M. Arababi, and H. Coker, "A screen for benzo(a)pyrene in fish samples from crude oil polluted environments." American Journal of Environmental Science, vol. 4, no. 2 , pp. 145-150, 2008.

[26] O. M. Wangboje and J. Okpobo, "Potential carcinogenic risk from polycyclic aromatic hydrocarbons in selected smoked fish species from a typical rural market in West Africa." International Journal of Research and Reviews in Applied Sciences, vol. 41, no. 1, pp. 1-9, 2019.

[27] J. N. Newstead, I.K. Cousins, and J.P. Giesy, "Predicted distribution and ecological risk assessment of a segregated hydrofluoranthene in 
the Japanese environment." Environmental Science and Technology, vol. 36, pp. 4761-4769, 2002.

[28] O. M. Wangboje and G. C. Innocent, "Heavy metal content in a smoke-dried Clariid fish species from selected markets in Aba, Abia state, Nigeria, West Africa." International Journal of Applied Science and Research, vol. 3, no. 2, pp. 194-202, 2020.

[29] New York State Department of Environmental Conservation, "Polychlorinated Biphenyls (PCBs) in five fish species from the New York-New Jersey Harbor Estuary." NYSDEC, Division of Fish, Wildlife and Marine Resources, 2004, 397pp.

[30] Commission Regulation, "Amending Regulation (EC) No 1881/2006. Setting maximum levels for certain contaminants in foodstuffs." No $629 / 2008$ of 2 July 2008.

[31] Hudson River National Resource Trustees, “ PCB concentrations in Mink prey items-Fish, frogs and small mammals collected from the Hudson River." State of New York U.S. Department of Commerce and U.S. Department of the Interior. Public Release Version. 2017, $520 \mathrm{pp}$.

[32] N. Brajenovic, I.B. Karaconji, and A. Juric, "Levels of polychlorinated biphenyls in human milk samples in European countries." Archives of Industrial Hygiene and Toxicology, vol. 69, pp. 135-153, 2018. doi:10.2478/aiht-2018-69-3120.

[33] C. Harkin, "A review on plastic bioaccumulation, potential health effects and the potential to enhance biotransformation using herbal medicine and nutritional supplements." International Journal of Complementary and Alternative Medicine, vol. 13, no.1, pp. 18-26, 2020.

[34] F. Mounier, L. Pecquerie, J. Lobry, A.E. Sardi, P. Labadie, H Budzinski, and V. Loizeau, "Dietary bioaccumulation of persistent organic pollutants in the common Sole Solea solea in the context of global change. Part 1: Revisting parameterization and calibration of a deb model to consider inter-individual variability in experimental and natural conditions." Ecological Modelling, vol.433, 2020 doi.org/10.1016/j.ecolmodel.2020.109224.

[35] X.P. Nie, C.Y. Lan, T.C. An, K.B. Li, and M.H. Wong, "Distributions and congener patterns of PCBs in fish from major aquaculture areas in the Pearl River Delta, South China." Human and Ecological Risk Assessment, vol.12, pp. 363-373. 2006. doi:10.10807030500537908.

[36] T. Brazova, V. Hanzelova, D. Miklisova, D. Salgovicova, and L. Turcekova, "Biomonitoring of polychlorinated biphenyls in heavily polluted aquatic environment in different fish species." Environmental Monitoring and Assessment, vol. 184, pp. 6553-6561, 2011. doi:10.1007/s10661-011-2440-9.

[37] S. Hardell, H. Tilanda, G. Welfinger-Smith, J. Burger, and D.O Carpenter, "Levels of polychlorinated biphenyls and three organochlorine pesticides in fish from the Aleutia Islands of Alaska." PLoS One, vol. 5, no. 8, pp. e12396, 2010. doi: 10.1371/journal.pone.0012396.

[38] Alabama Fish Consumption Advisories, "Fish consumption advisories for 2020." Alabama Department of Public Health/Alabama Department of Environmental Management/Alabama Department of Conservation and Natural Resources/Tennessee Valley Authority, 2020, $38 \mathrm{pp}$.

[39] O.M. Wangboje, F.A. Oguzie, and J. Ufua, "Heavy metals in Heterobranchus logifilis (Cuvier and Valenciennes, 1840) cultured in earthen ponds in selected communities in Warri metropolis, Nigeria." Uganda Journal of Agricultural Sciences, vol. 18, no.2, pp. 67-82, 2018.

[40] A. Hoffer, B. Jancsek-Turoczi, A. Toth, G. Kiss, A. Naghiu, E.A. Levei, L. Marmureanu, A. Machon, and A. Gelencser, "Emission factors for PM 10 and PAHs from illegal burning of different types of municipal waste in households." Atmospheric Chemistry and Physics, 2020. doi.org/10.5194/acp-2020-672.

[41] Food and Agriculture Organisation of the United Nations, "Compilation of legal limits for hazardous substances in fish and fishery products.” FAO Fishery Circular, 1983, Number 464.

[42] Agency for Toxic Substances and Disease Registry. "Polychlorinated biphenyl toxicity: What standards and regulations exist for PCB exposure." Available:www.atsdr.cdc.gov/csem/csem.asp Accessed August $3^{\text {rd }}, 2020$.

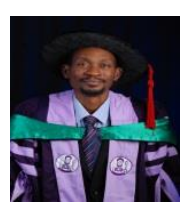

Wangboje, M. Oiseoje (ORCID: 0000-0001-75873883) is a Senior Lecturer and Researcher in the Department of Aquaculture and Fisheries Management, Faculty of Agriculture, University of Benin, Benin City, Nigeria. Dr. Wangboje was born in Zaria, Kaduna State, Nigeria and received his tertiary education at the University of Benin. He holds a B.Sc. Degree in Zoology (Second Class, Upper)-1995; M.Sc. Degree in Fisheries (1999) and a Ph.D in Fisheries (2013). He specializes in Fish biology and Ecotoxicology /Ecological Risk Assessment. He teaches water pollution, limnology, fish biology, aquatic flora and fauna, fish parasites and disease, Oceanographic techniques and land use planning. His publications span across Local, National and International peer-reviewed journals of high repute, including Asian Journal of Environment and Ecology, International Journal of Fisheries and Aquatic Studies, Ethiopian Journal of Environmental Studies and Management, International Journal of Applied Science and Research and International Journal of Research and Reviews in Applied Sciences. He is a member of the Fisheries Society of Nigeria (FISON) and the Global Youth Network on Biodiversity.

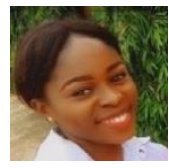

Obotha-Adigo, Oghenefejiro (ORCID: 0000-0002-67885494) was born in Asaba, Delta State, Nigeria. She earned a Bachelor of Agriculture Degree in Fisheries in 2019 from the University of Benin. She is a budding Ecotoxicologist under the tutelage of Dr. O.M. Wangboje, the principal investigator. 